\title{
CLIMATIC DATA FOR THE COTTONWOOD LAKE AREA, STUTSMAN COUNTY, NORTH DAKOTA 1983
}

By

A.M. Sturrock, B.A. Hanson, JL. Scarborough, and T.C. Winter

U.S. GEOLOGICAL SURVEY

Open-File Report 87-216

Prepared in cooperation with

U.S. FISH AND WILDLIFE SERVICE

NORTHERN PRAIRIE WILDLIFE RESEARCH CENTER

Lakewood, Colorado 1987 


\section{DEPARTMENT OF THE INTERIOR \\ DONALD PAUL HODEL, Secretary}

U.S. GEOLOGICAL SURVEY

Dallas L. Peck, Director

For additional information write to:

Thomas C. Winter

U.S. Geologica1 Survey Water Resources Division

Box 25046, Mail Stop 413

Federal Center

Denver, CO 80225
Copies of this report can

be purchased from:

U.S. Geological Survey

Books and Open-File Reports Section

Federal Center

Box 25425

Denver, CO 80225 


\section{CONTENTS}

Page

Abstract-

Introduction-1 1

Data collection and presentation- 1

References-0.- 2

\section{FIGURES}

Figures 1-3. Graphs showing:

Page

1. Dry-bulb and wet-bulb air temperatures at the raft station--...- 26

2. Temperature of water at surface and at $20 \mathrm{~cm}$ above lake bottom at the raft station-.-. 27

3. Temperature of sediment at depths of 0.5 and $1.0 \mathrm{~m}$ at the raft station-.... 28

\section{TABLES}

Table 1. Summary of 1983 energy-budget data-

2. Summary of 1983 temperature data at the raft station--_-_-- 14

3. Summary of 1983 wind-speed data at the raft station-_-_-_-- 17

4. Summary of 1983 radiation data at the land station-....... 22 
METRIC CONVERSION FACTORS

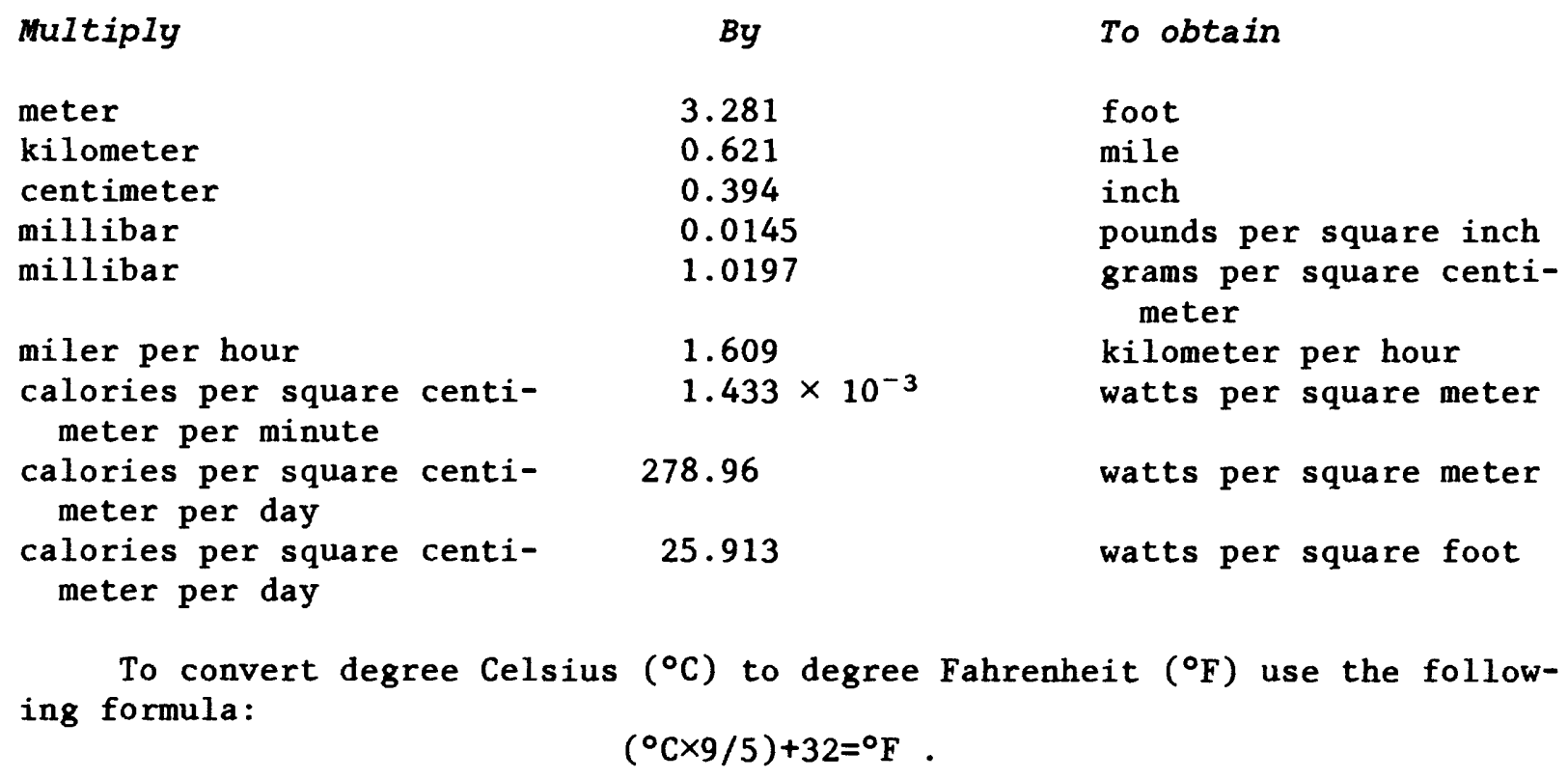


CLIMATIC DATA FOR THE COTTONWOOD LAKE AREA, STUTSMAN COUNTY, NORTH DAKOTA

1983

By A.M. Sturrock, B.A. Hanson, J.L. Scarborough, and T.C. Winter

\begin{abstract}
Research on the hydrology of the Cottonwood Lake area, Stutsman County, North Dakota, includes study of evaporation. Presented here are those climatic data needed for energy-budget and mass-transfer evaporation studies that were collected during 1983, including: water-surface temperature, sediment temperature, dry-bulb and wet-bulb air temperatures, vapor pressure at and above the water surface, wind speed, and short- and long-wave radiation. Data are collected at raft and land stations.
\end{abstract}

\title{
INTRODUCTION
}

Climatic data are being collected at the Cottonwood Lake area as part of a continuing study of the hydrology of a group of small lakes and wetlands by the U.S. Geological Survey and the U.S. Fish and Wildlife Service. The Cottonwood Lake area is one of several lake areas in different parts of the United States that have been selected for intensive study of hydrological and related chemical and biological processes. The rationale for selection of the Cottonwood Lake area is given by Winter and Carr (1980). Climatic data for the 1982 open-water season are given in Sturrock and others (1986).

\section{DATA COLLECTION AND PRESENTATION}

Data presented here are being collected principally for studies of evaporation; therefore, data are collected only during the time the lakes and wetlands are ice-free. Data for 1983 were collected from May 18 (Julian day 138) to September 20 (Julian day 263). Within each table, the data are grouped according to energy-budget periods; the periods are defined by the dates thermal survey were made in the water body. For example, the first energy-budget period for 1983 is Julian days 138 through 144 .

Climatic instruments are located at a raft station near the middle of wetland $\mathrm{P} 1$ and at a land station. Instruments at the raft station include anemometers at 2 and 3 meters above the water surface, a thermistor psychrometer with dry-bulb and wet-bulb temperature sensors at 2 meters above the water surface, and water-temperature sensors beneath the raft at a depth of about 1 centimeter below the water surface and 20 centimeters above the sediments. This second water-temperature sensor is referred to in the tables as "lake bottom water temperature". Sediment-temperature sensors are at 0.5 and 1.0 meter below the sediment-water interface. 
Data from the above sensors are recorded by a digital data logger located on the raft. The data logger scans the sensors every minute and calculates hourly and daily averages and totals. In addition, for selected sensors, maximum and minimum values and the times they occur are stored and recorded at midnight of each day. Additional analog instruments for measuring watersurface temperature and wind speed also are located on the raft. These are used to backup the primary instruments for quality control and for filling in missing data.

The land station consists of short- and long-wave radiometers. These data also are recorded by a digital-data logger that operates similarly to the one on the raft. A backup hygrothermograph that records air temperature and relative humidity is located on the shore near wetland P1. Calibration checks with laboratory-quality thermometers and motorized psychrometers are made weekly. Vapor pressure of water $(e)$ is calculated using water-temperature data and assuming the air is completely saturated at the air-water interface.

Data presented here are daily summaries. For periods during which the primary instruments were not operating properly, daily values were obtained by regression using data from backup instruments, provided a satisfactory statistical relationship could be established. Data used to establish regressions were selected so they bracketed the period of missing or inadequate data. Only table 1, which is considered to be the primary source of data for evaporation studies, includes values obtained by regression. The data in table 2 terminate at Julian day 183 because maximum and minimum dry-bulb air temperatures were not recorded after that day. The data in table 3 begin at Julian day 180 because maximum and minimum radiation values were not recorded before that day. Graphs of daily average air temperature are shown in figure 1 , of daily average water temperature in figure 2, and daily average sediment temperatures in figure 3.

Although only daily values are reported here, hourly values also were recorded. Hourly values are voluminous and expensive to reproduce, but they are available for all or part of the period of record, on request to T.C. Winter.

\section{REFERENCES}

Koberg, G.E., 1964, Methods to compute long-wave radiation from the atmosphere and reflected solar radiation from a water surface: U.S. Geological Survey Professional Paper 272-F, p. 107-136.

Sturrock, A.M., Hanson, B.A., Scarborough, J.L., and Winter, T.C., 1986, Climatic data for the Cottonwood Lake area, Stutsman County, North Dakota, 1982: U.S. Geological Survey Open-File Report 86-477, 24 p.

Winter, T.C. and Carr, M.R., 1980, Hydrologic setting of wetlands in the Cottonwood Lake area, Stutsman County, North Dakota: U.S. Geological Survey Water-Resources Investigations 80-99, $42 \mathrm{p}$. 

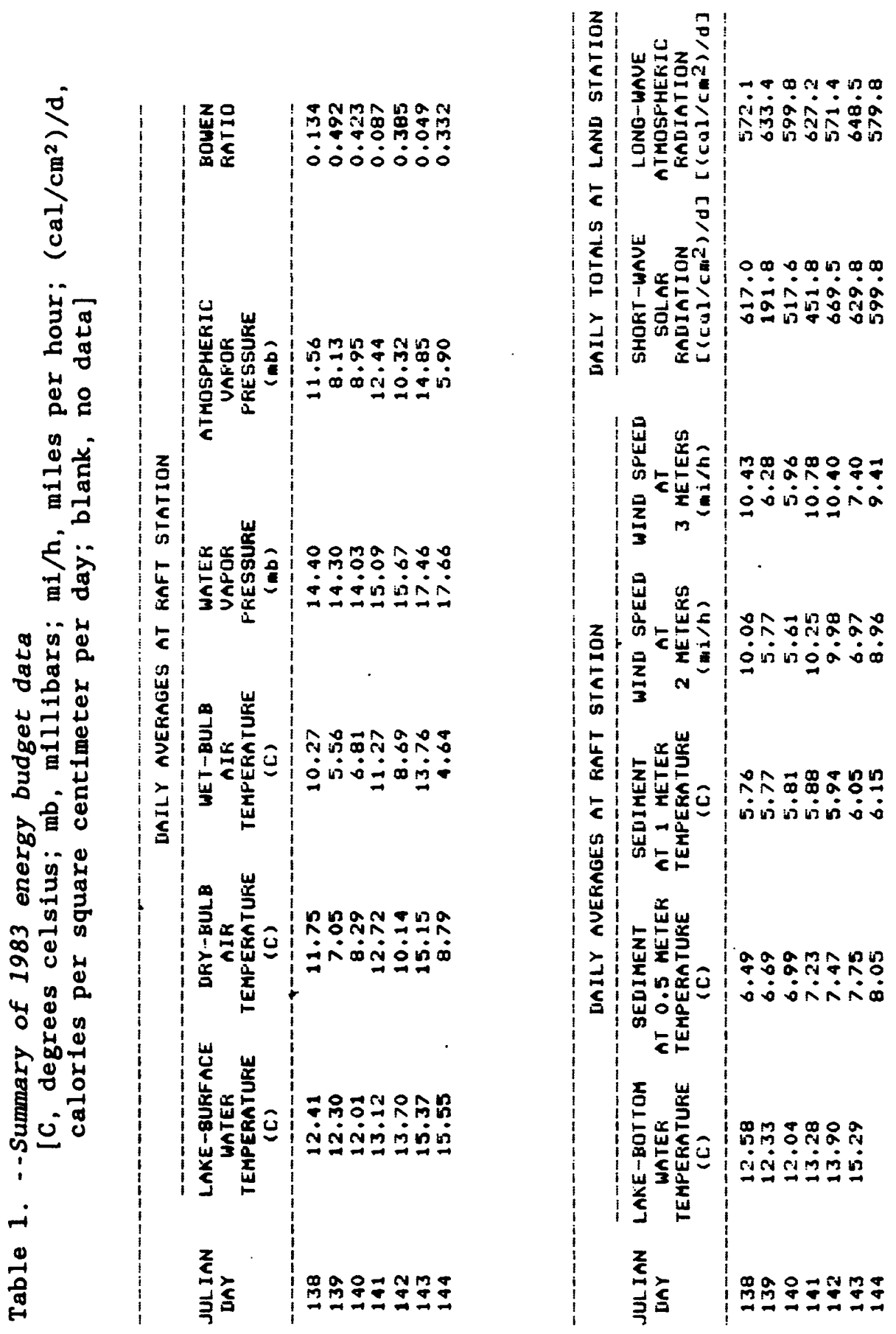

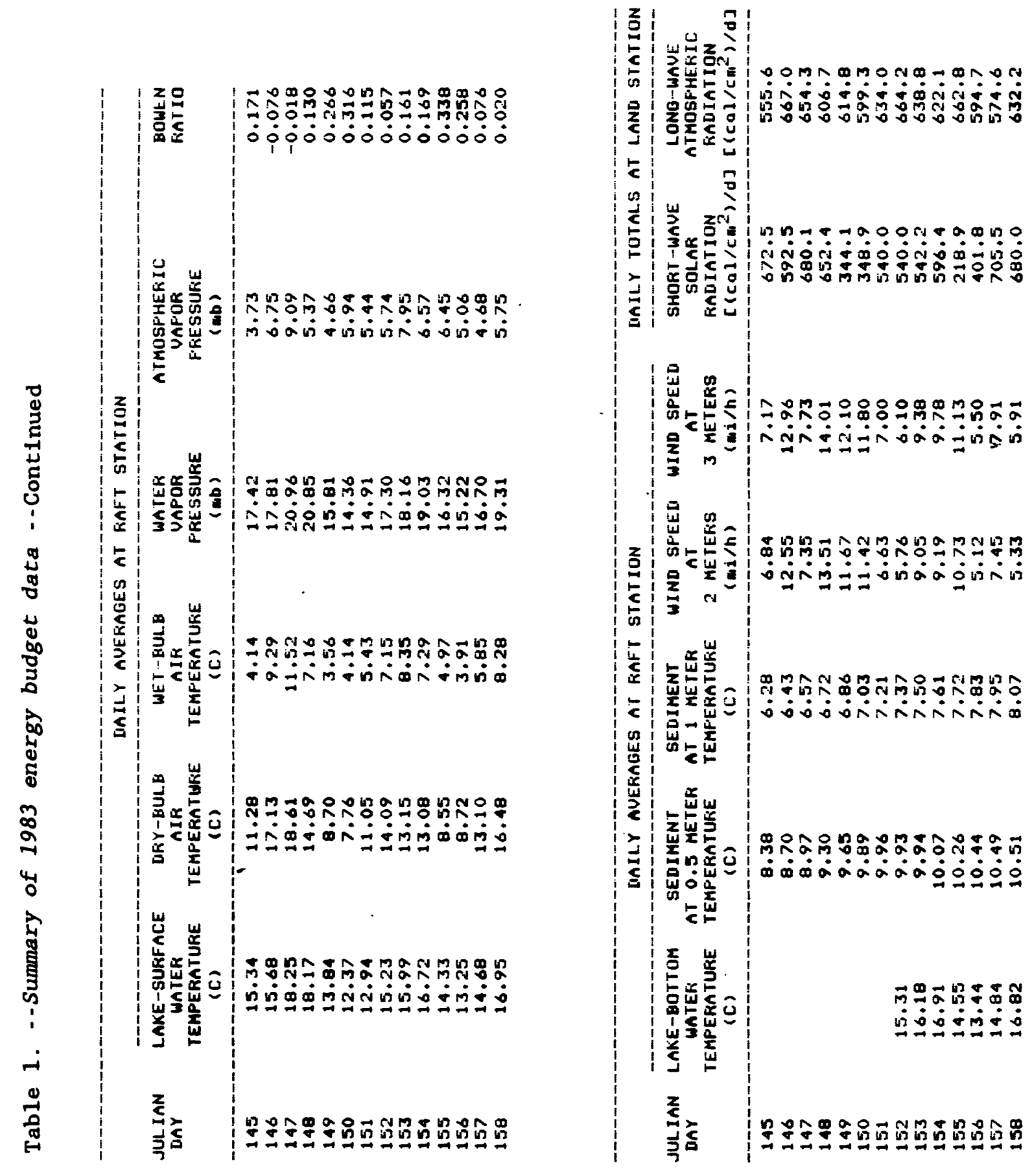

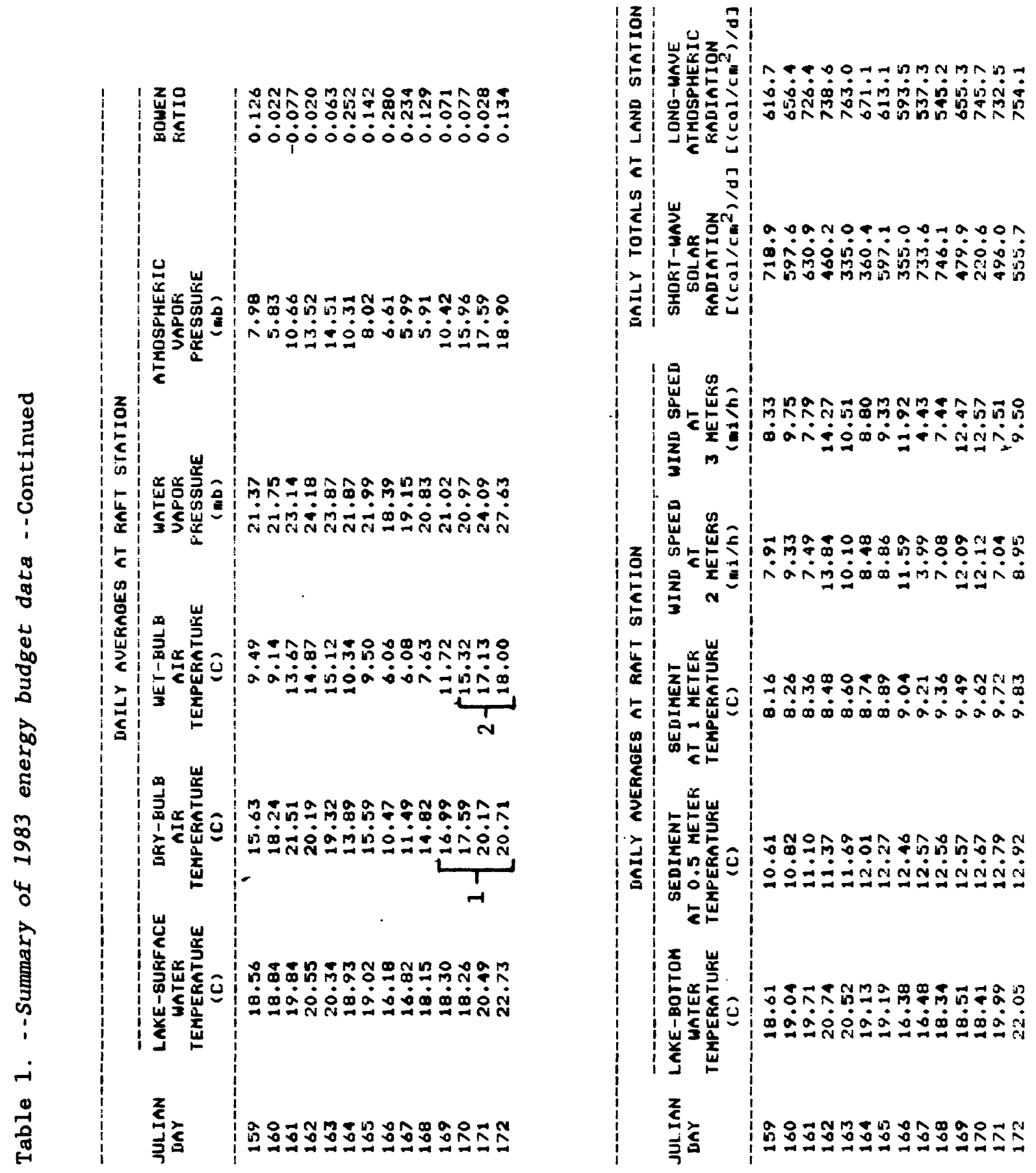


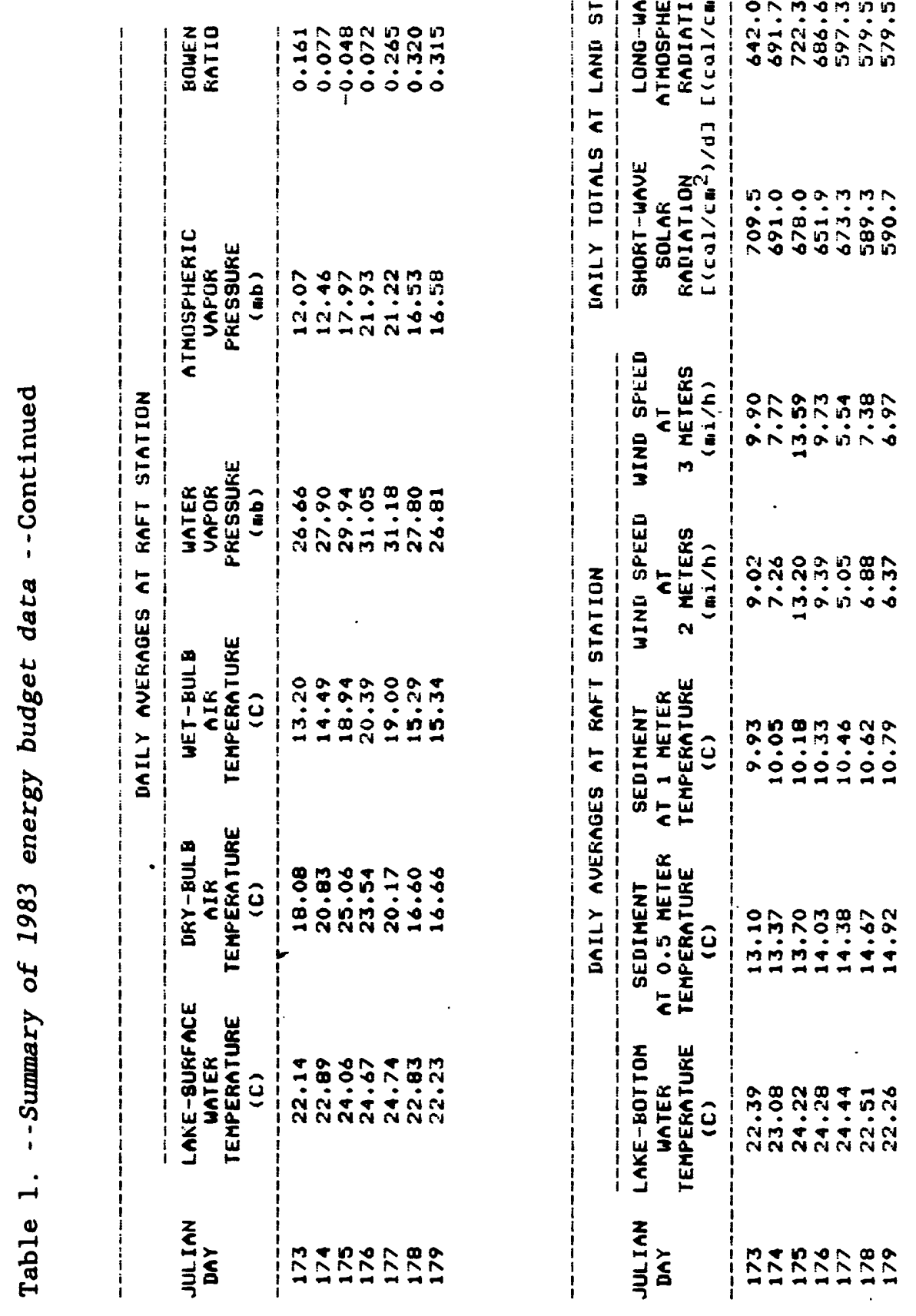



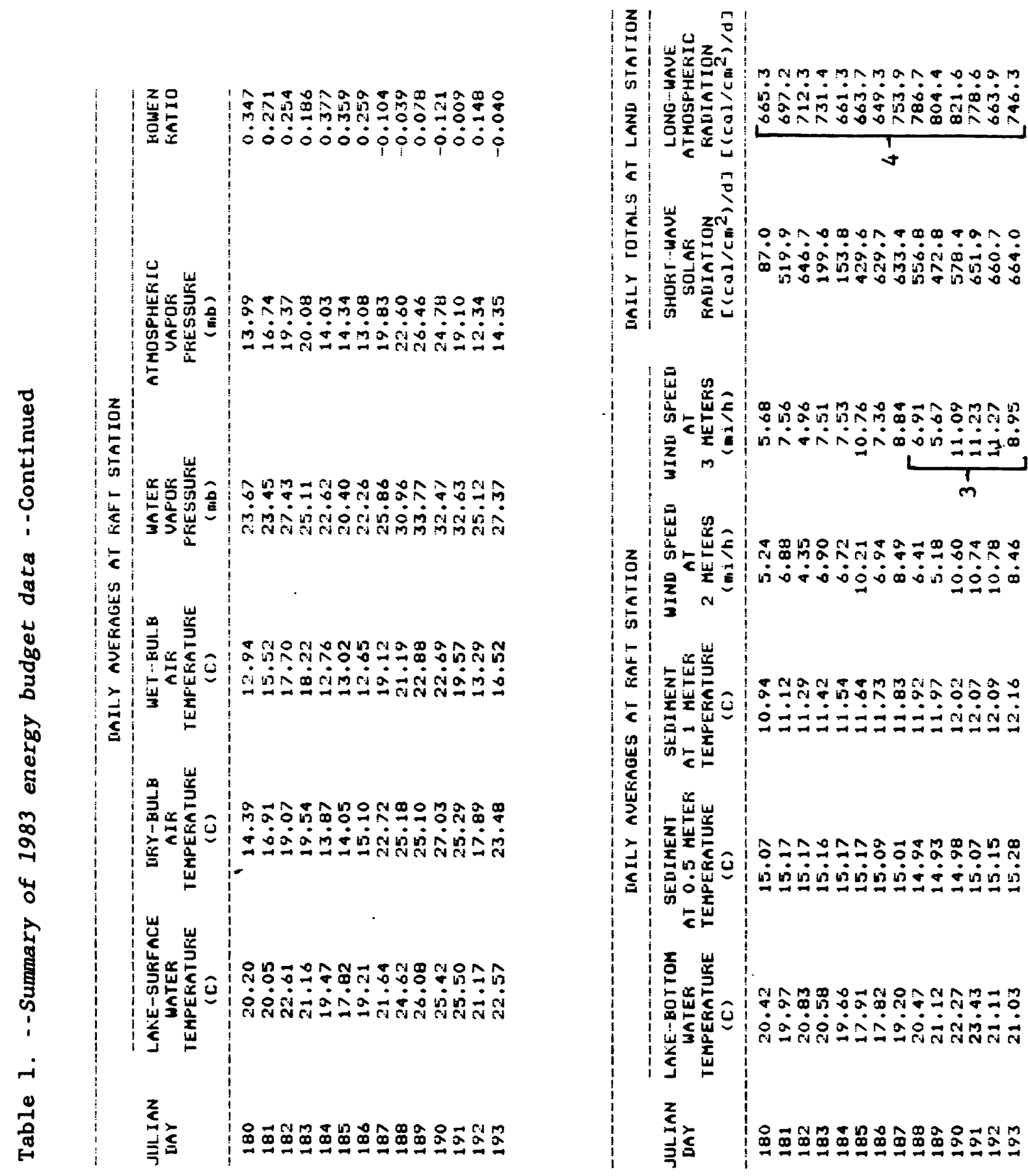

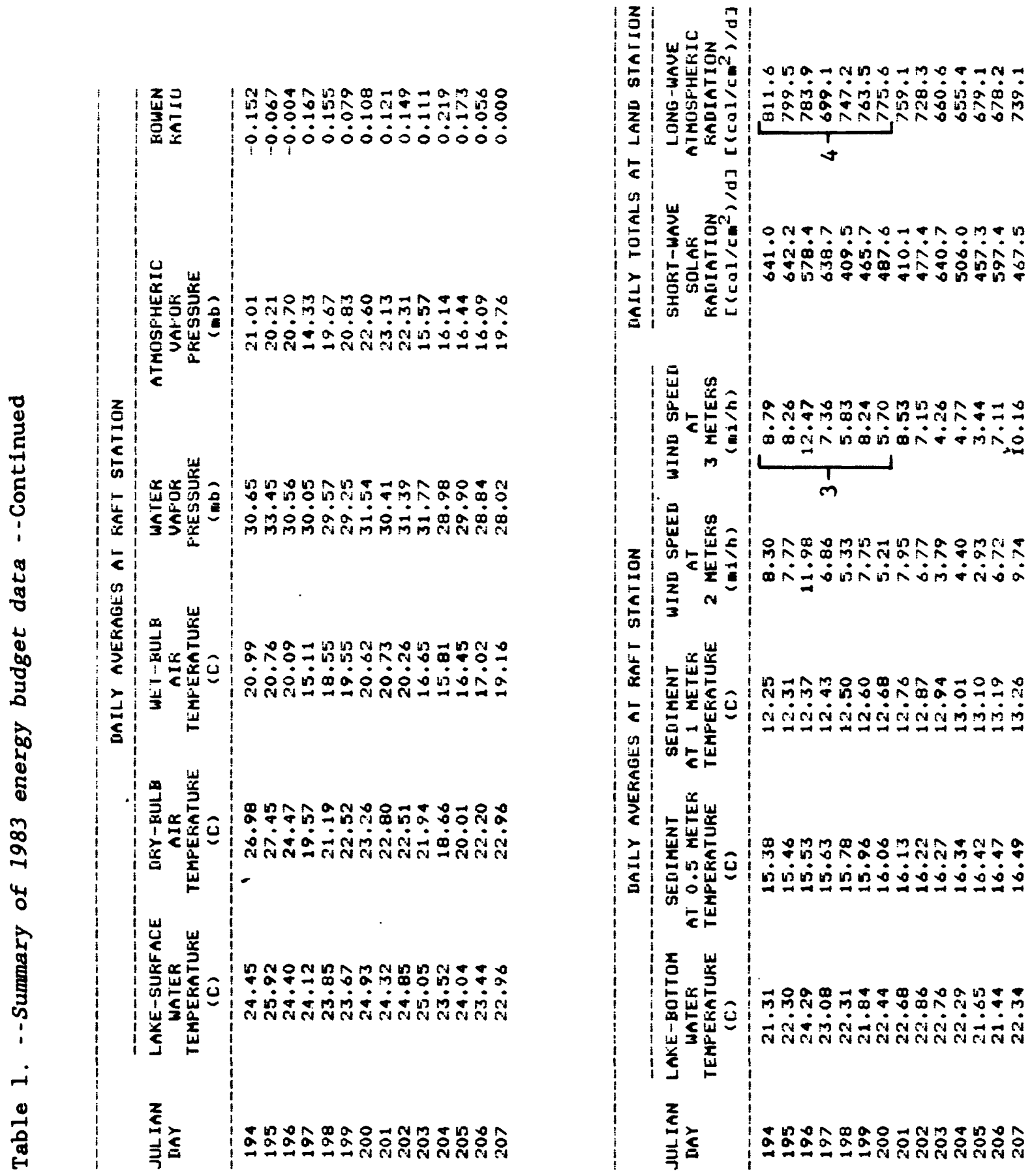

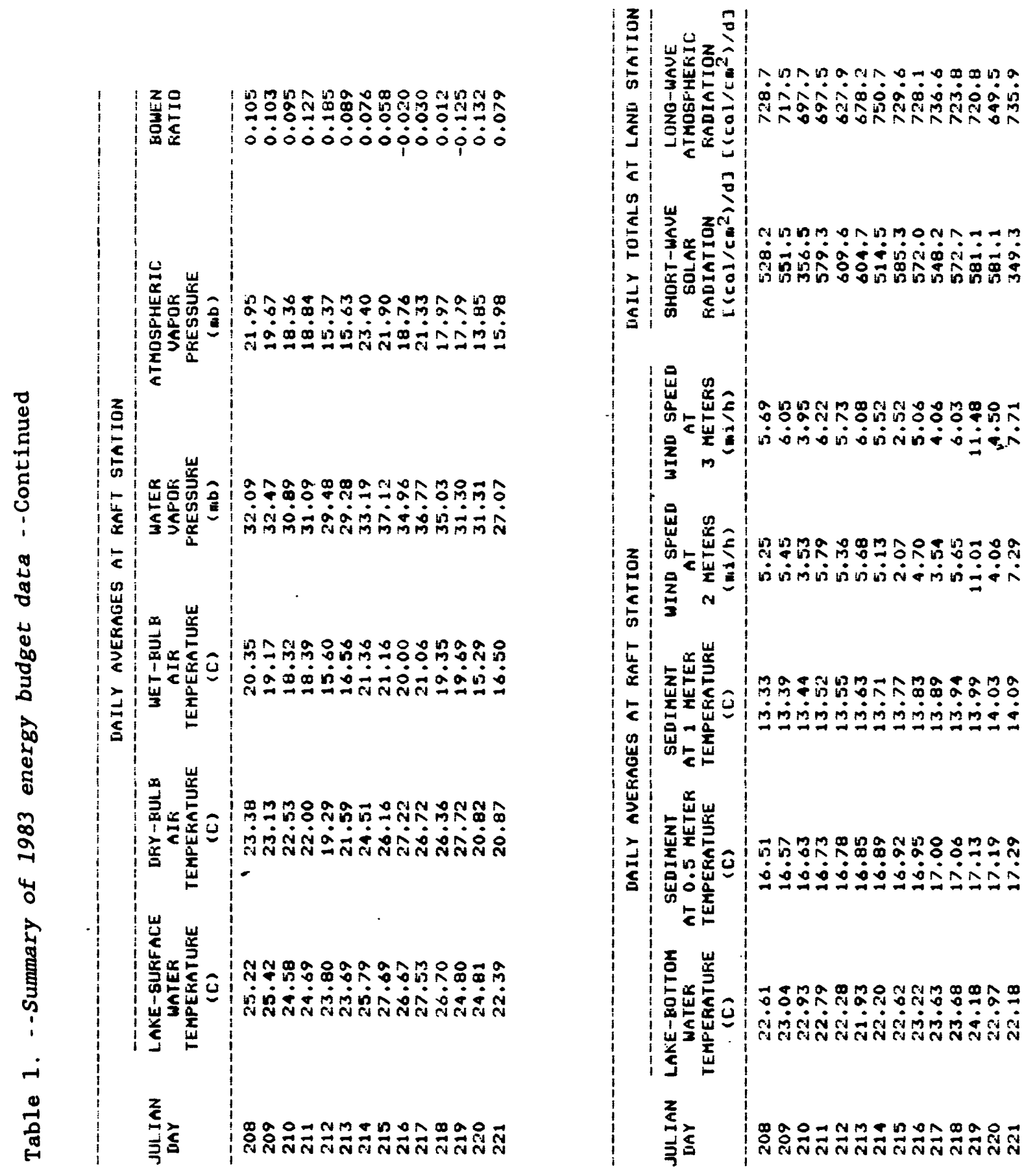

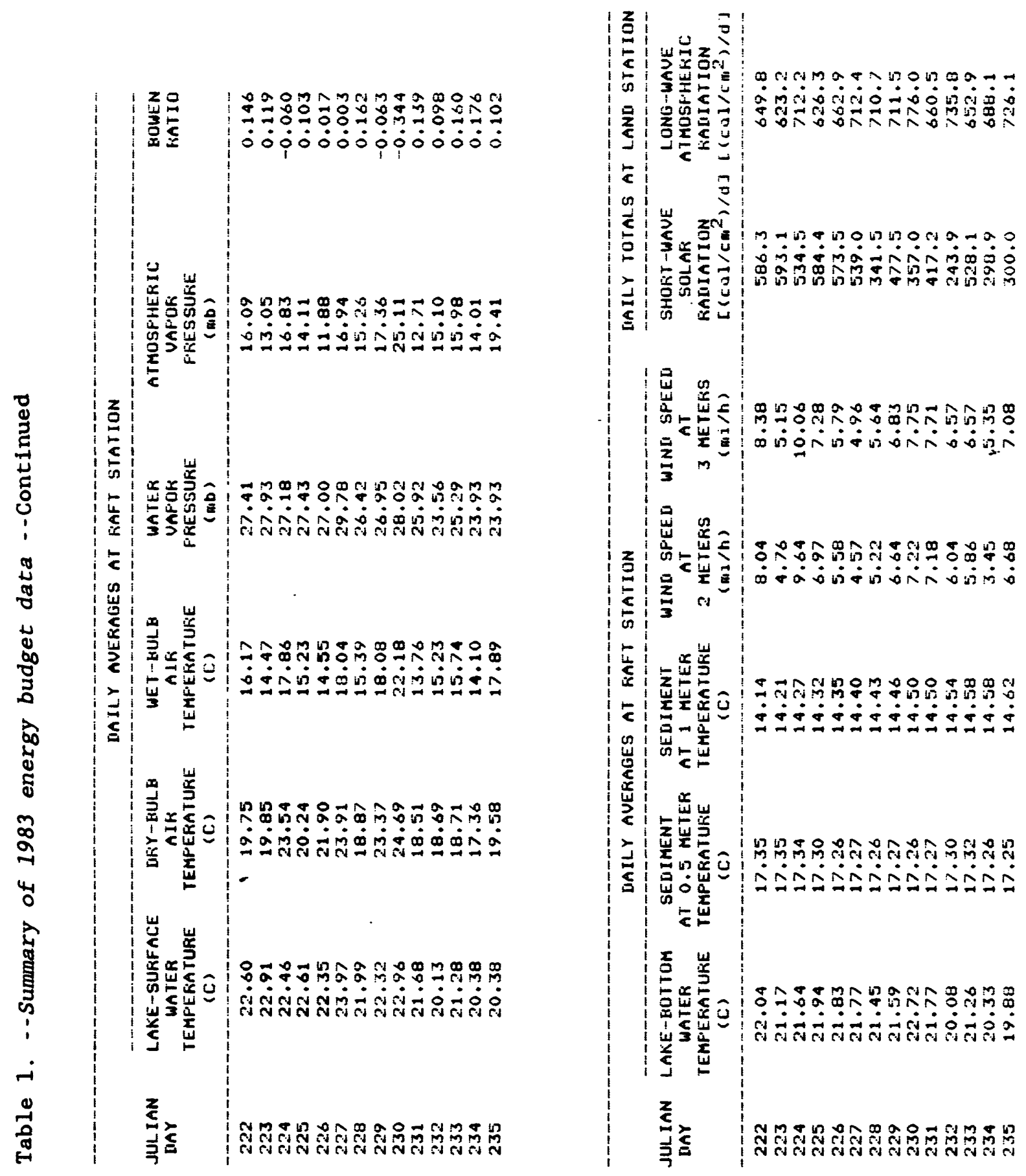

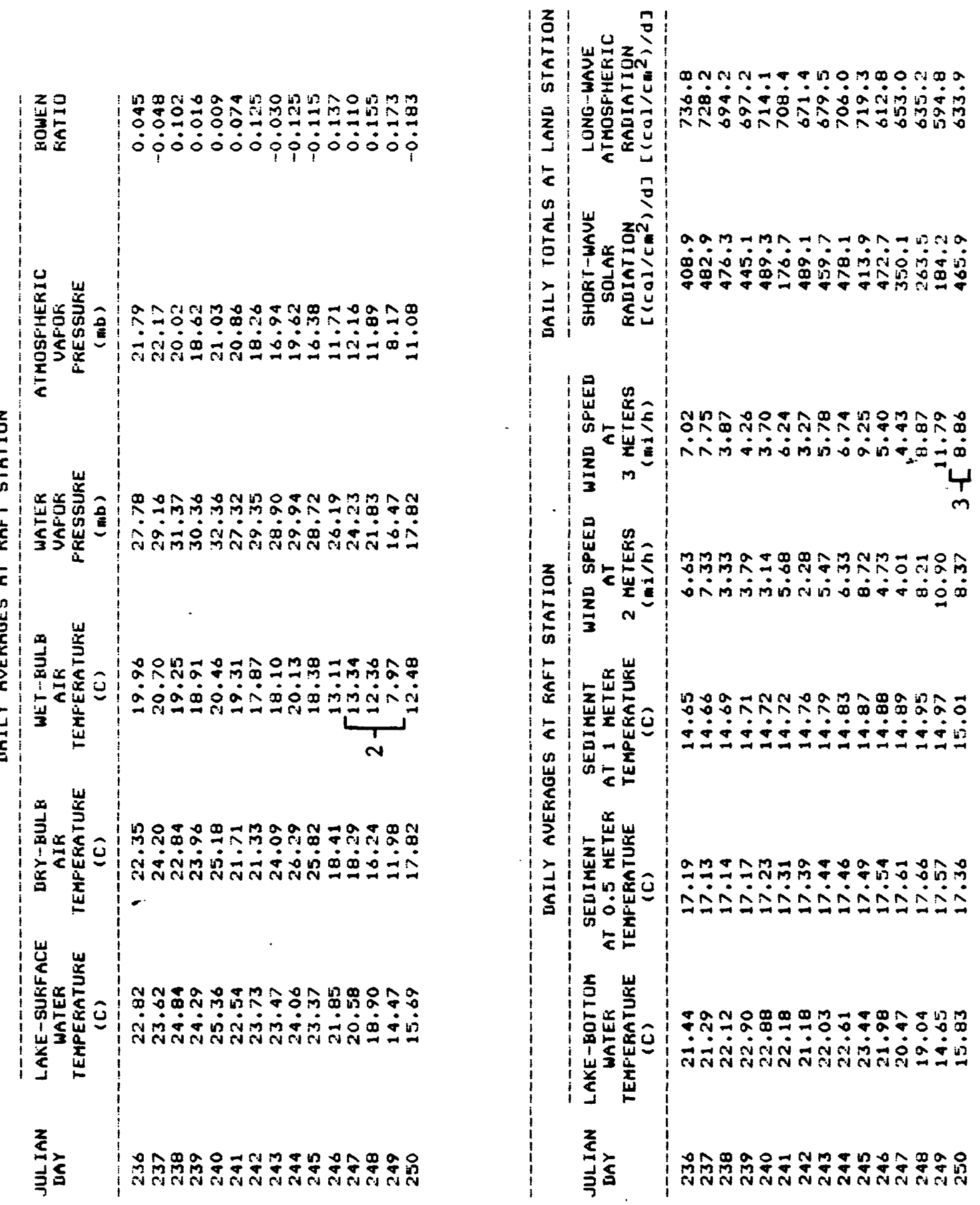

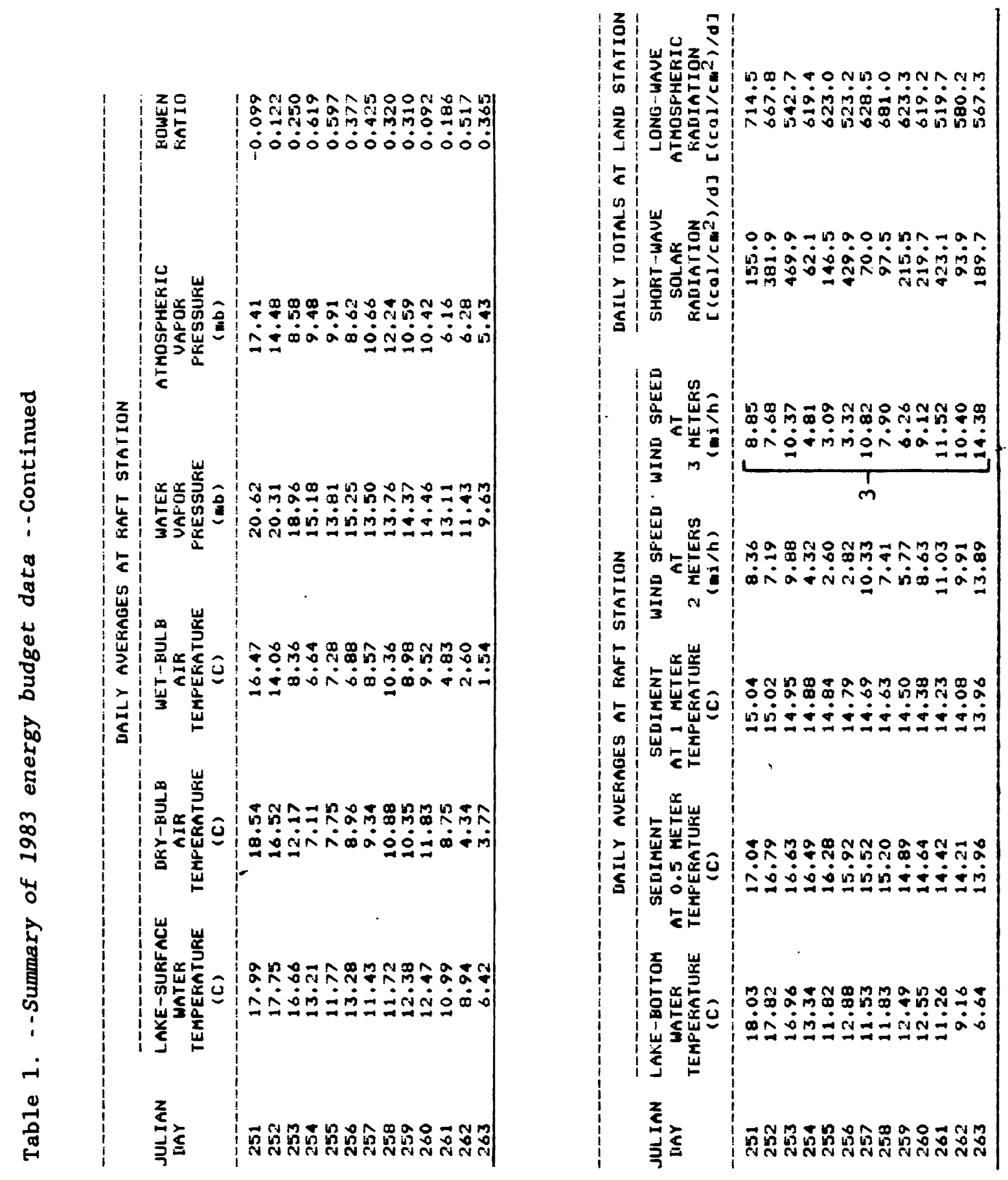
Footnotes to table 1:

1. Calculated by regression equation 1 (see below), which was determined by using air-temperature data from the hygrothermograph and the drybulb sensor connected to the digital data logger.

2. Calculated by regression equation 2 (see below), which was determined by using humidity data from the hygrothermograph, the pychrometric tables, and the wet-bulb sensor connected to the digital data logger.

3. Calculated by regression equation 3 (see below), which was determined by using wind data from the totalizing anemometer and the 2-meter anemometer connected to the digital data logger.

4. Calculated using Brunt's equation (Koberg, 1964).

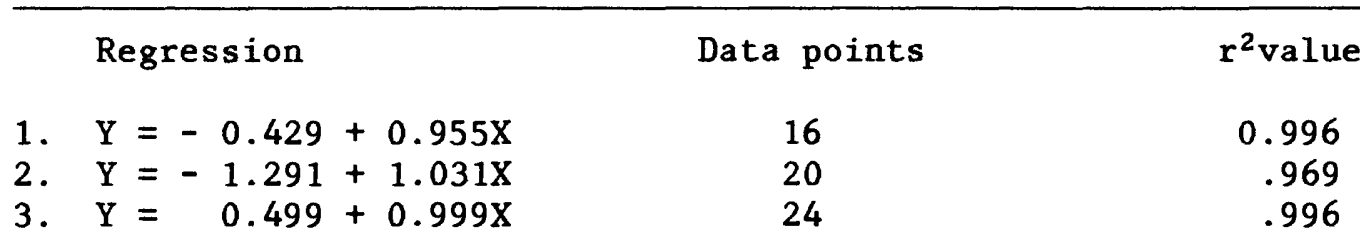



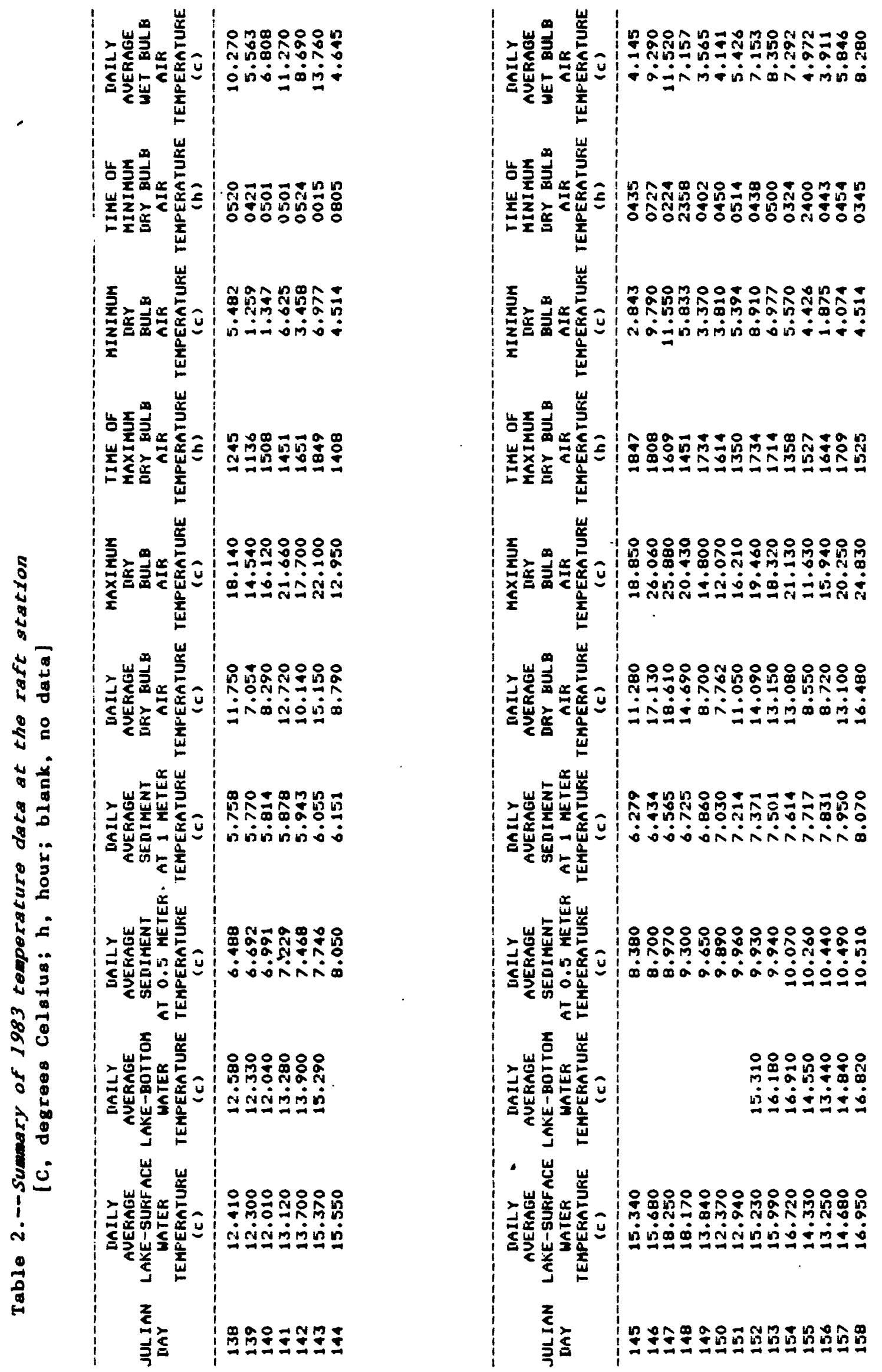

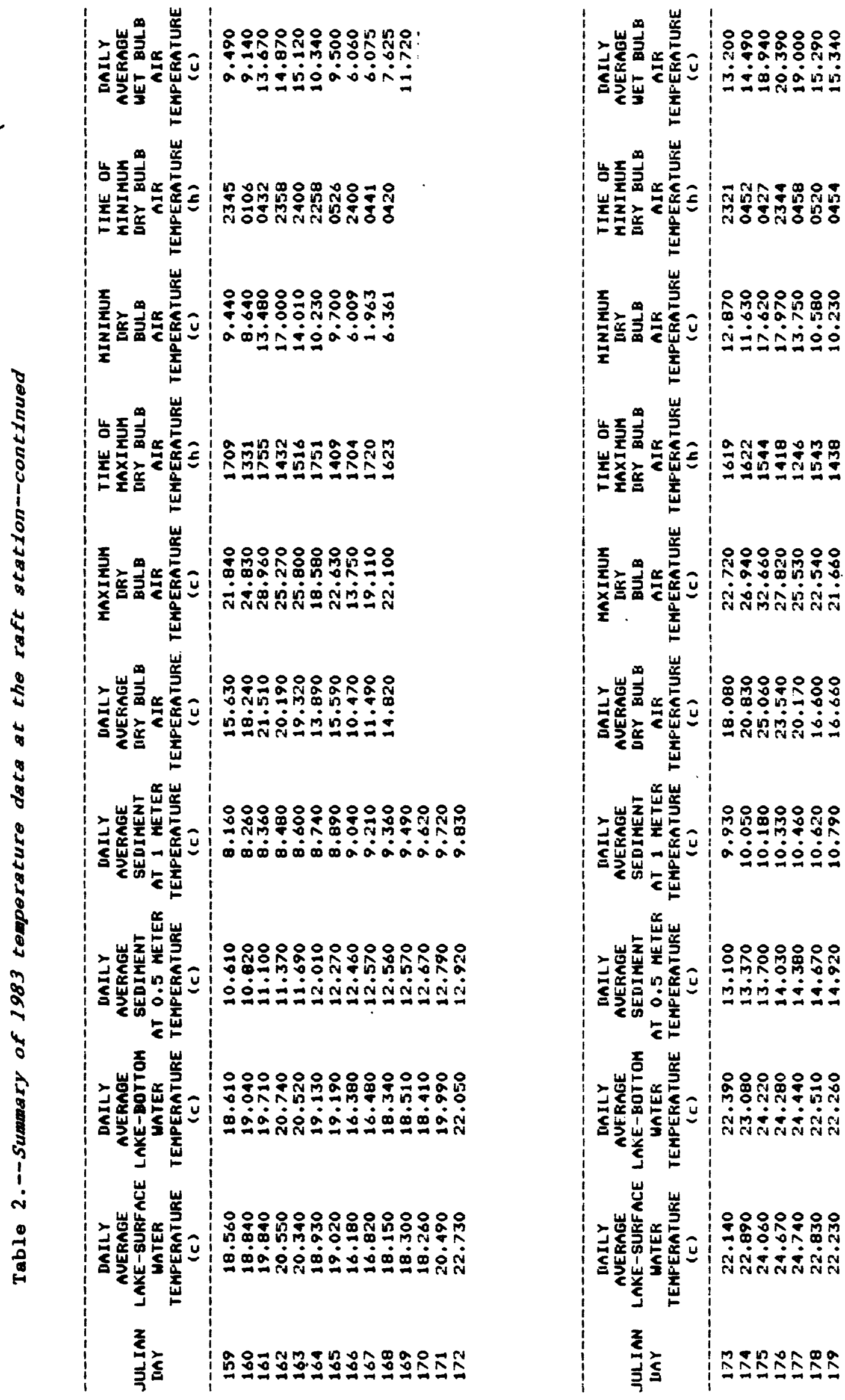


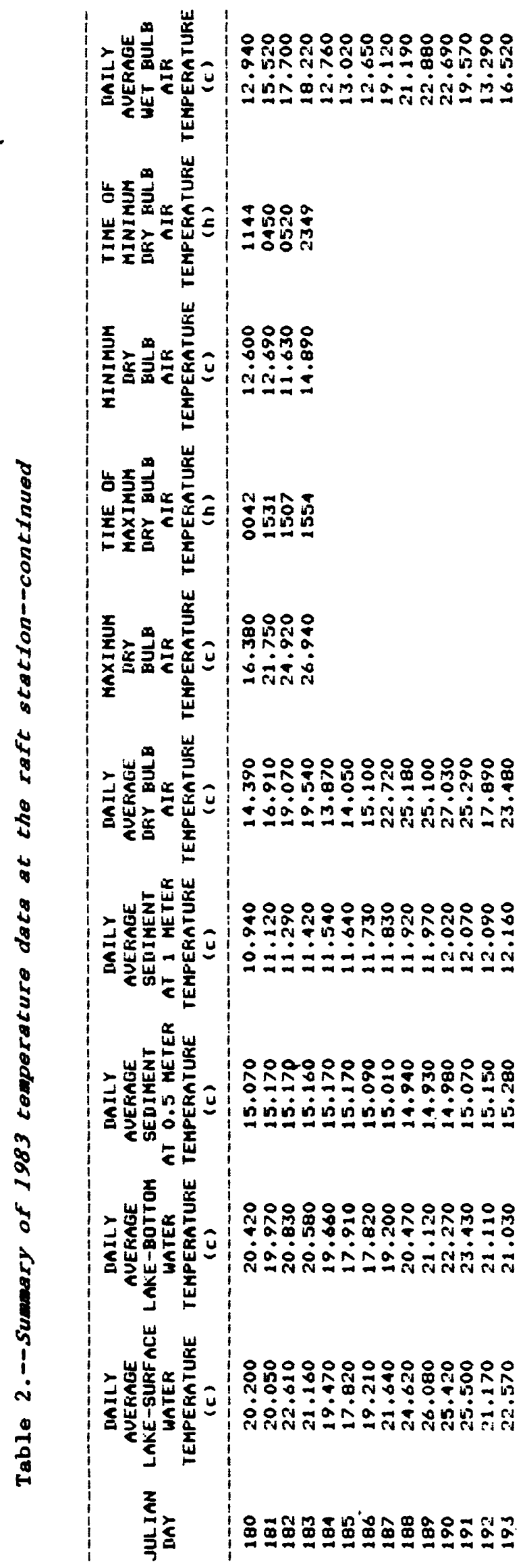

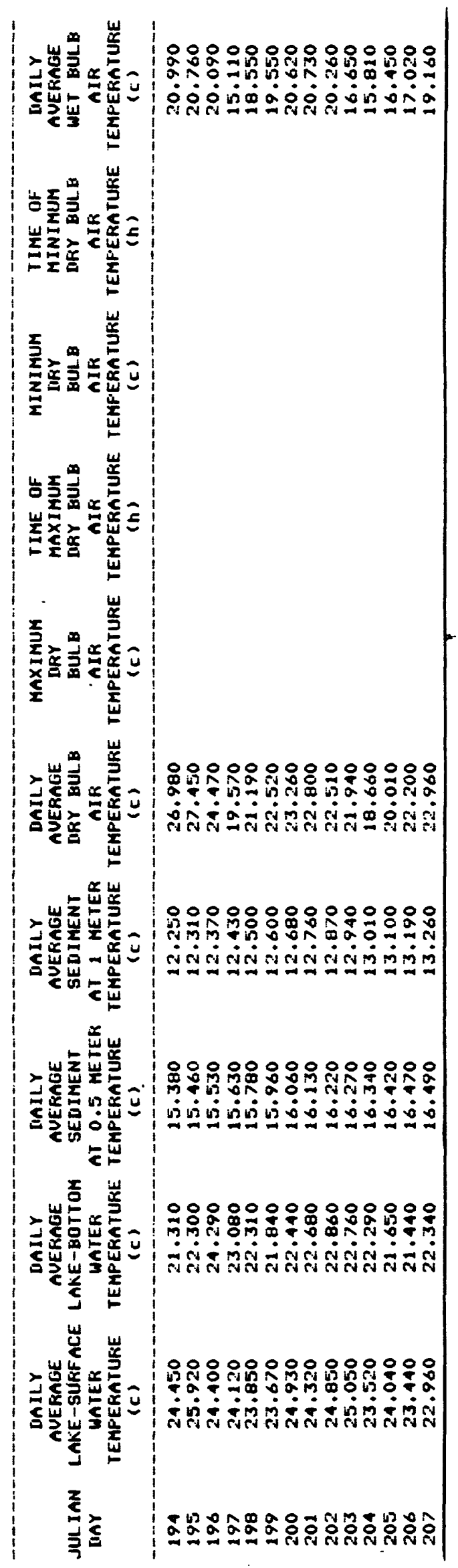



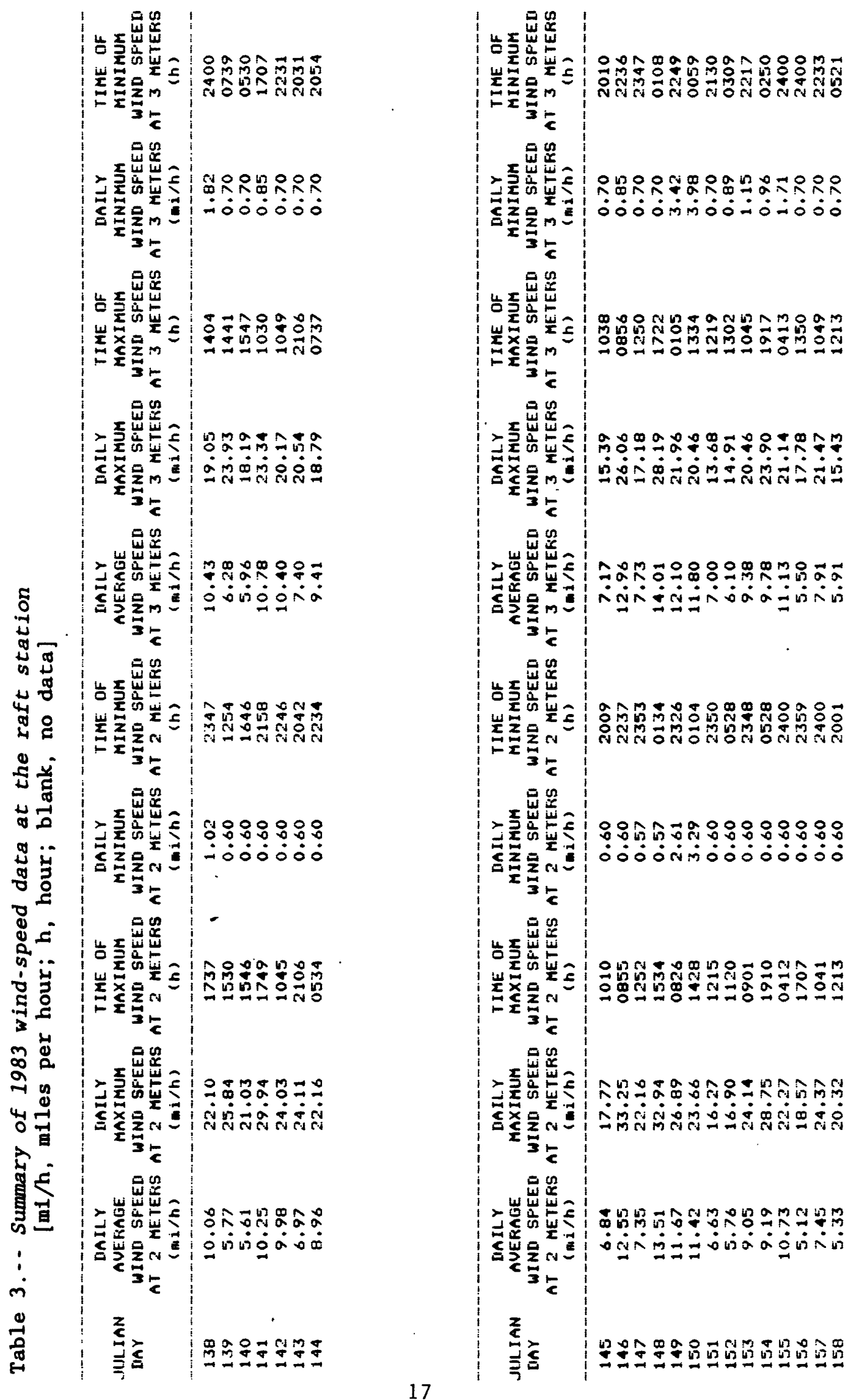

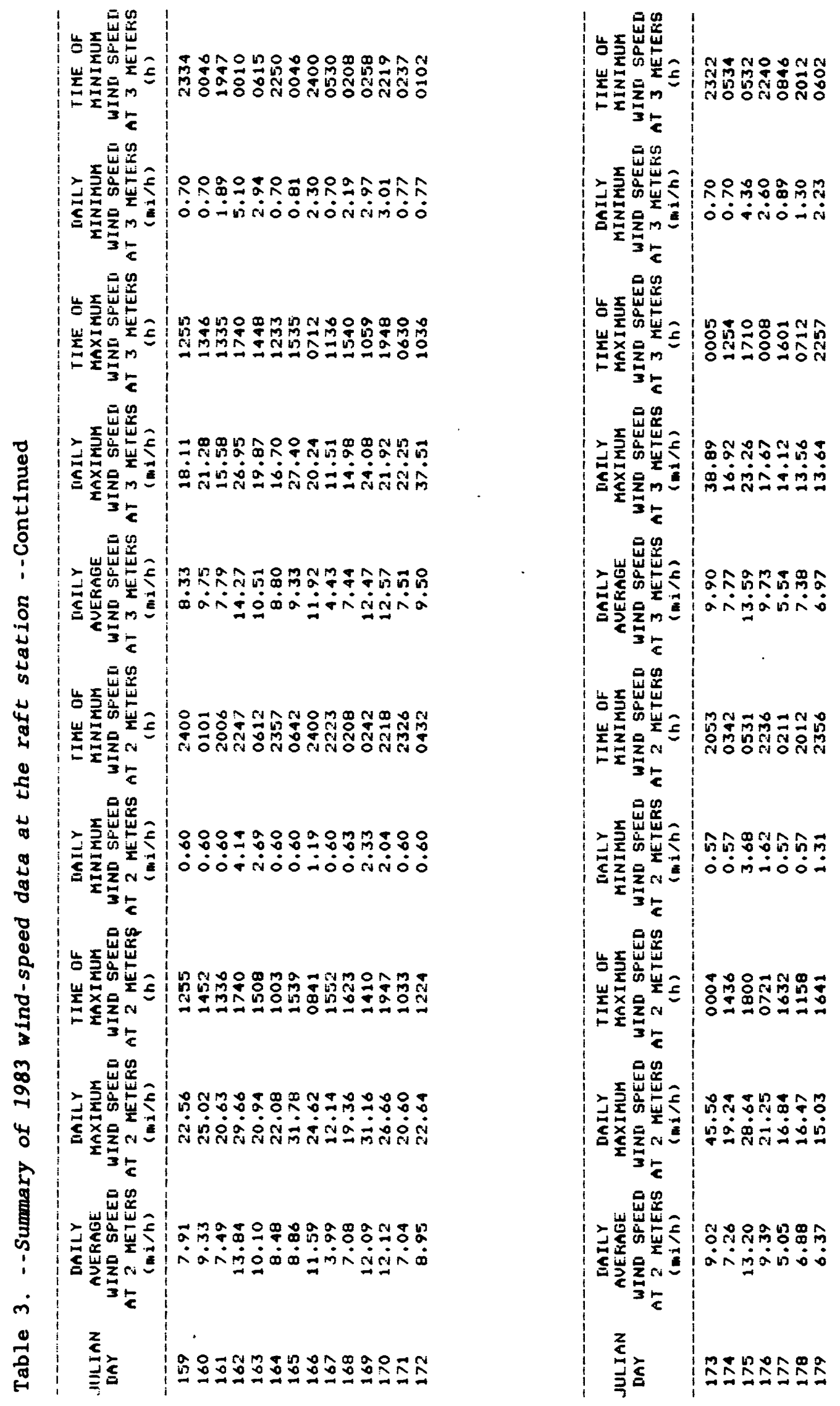

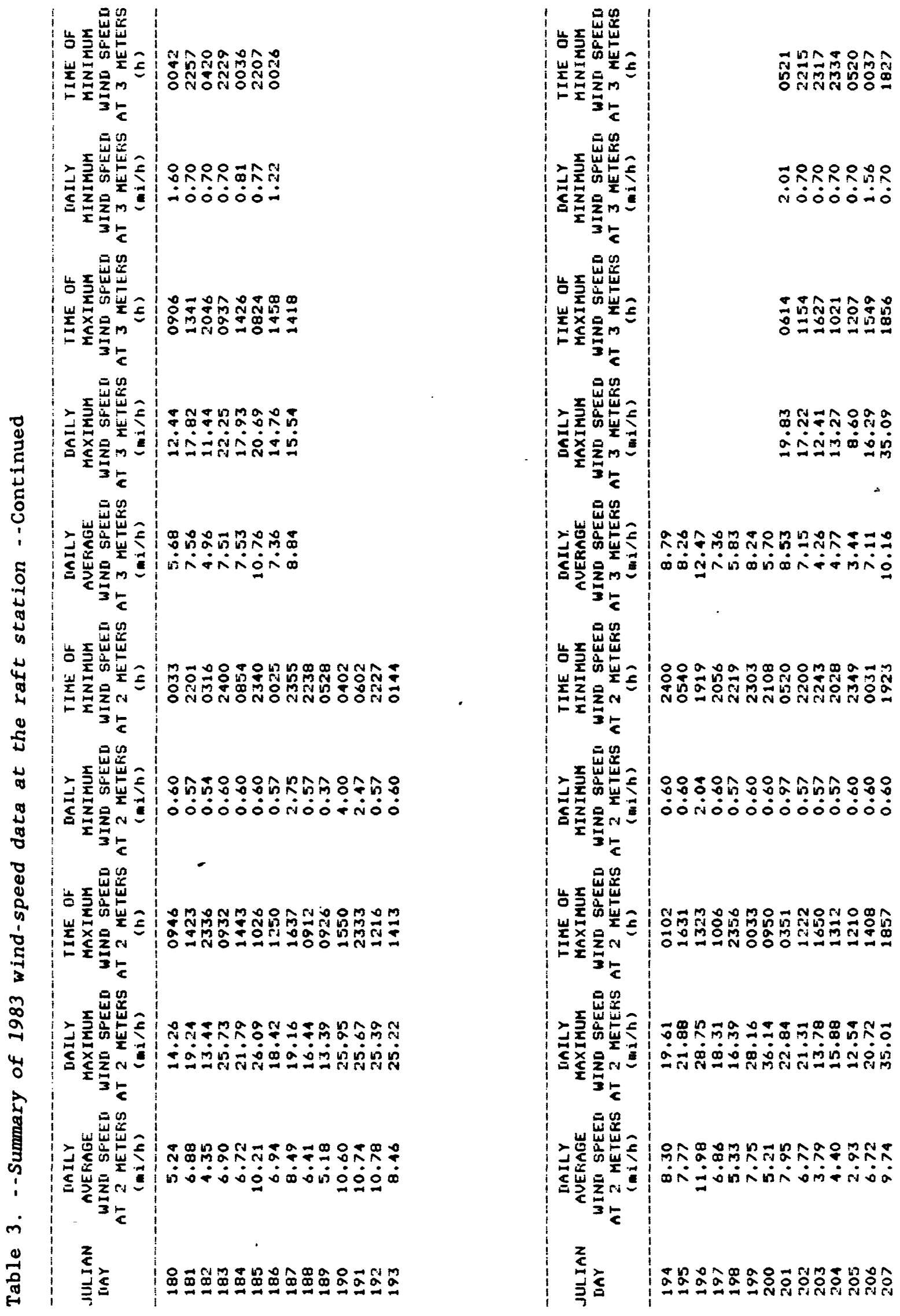

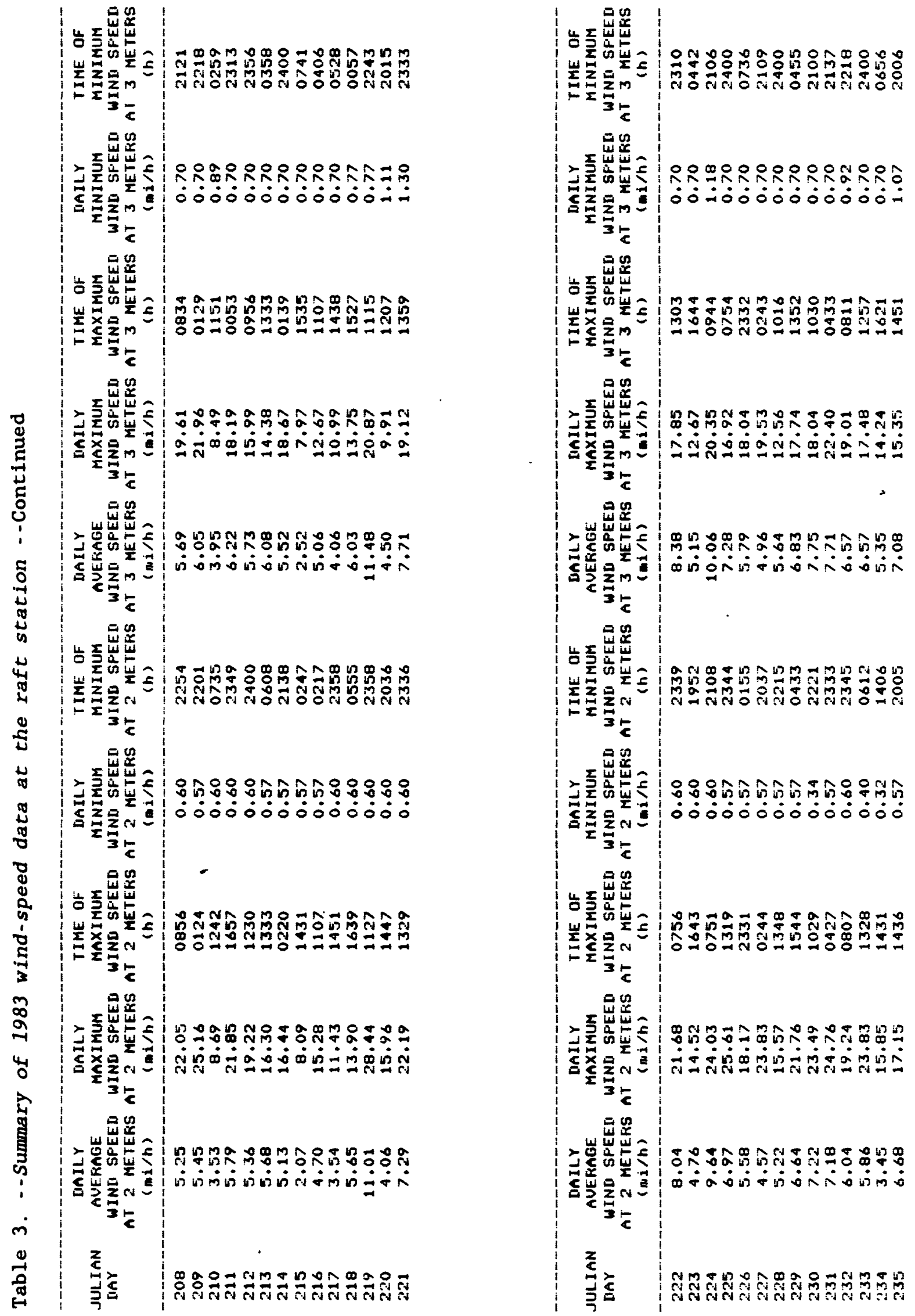

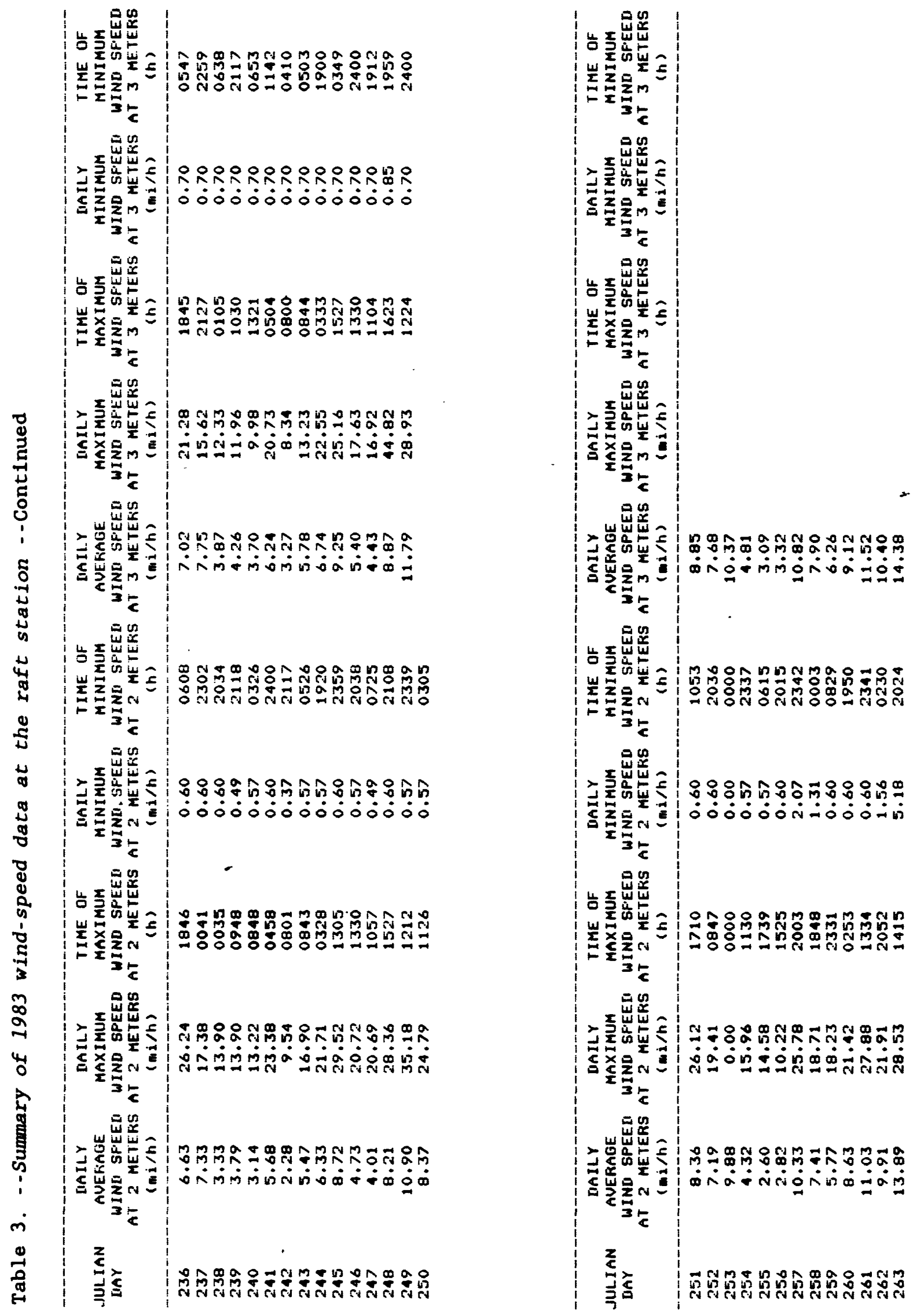

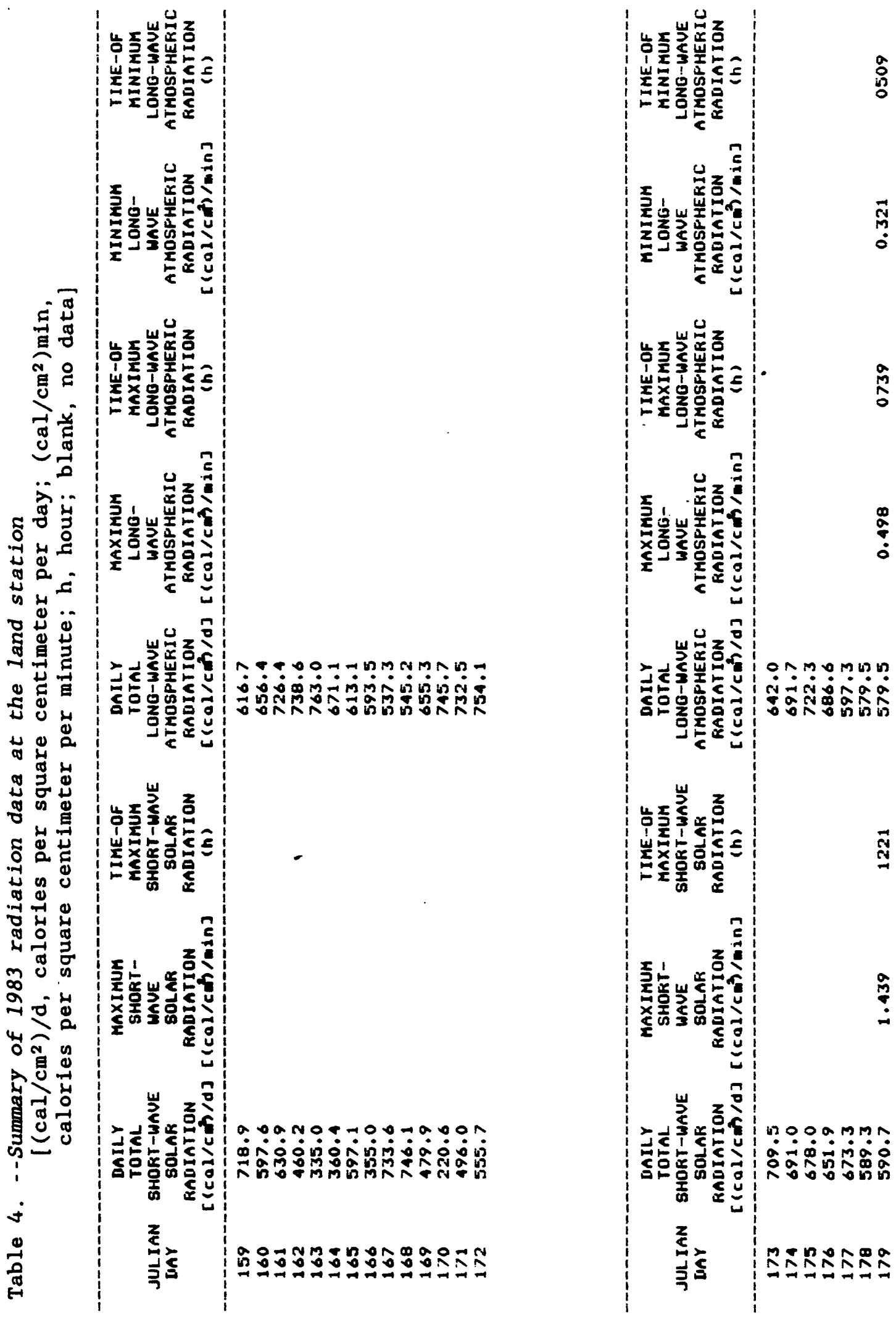

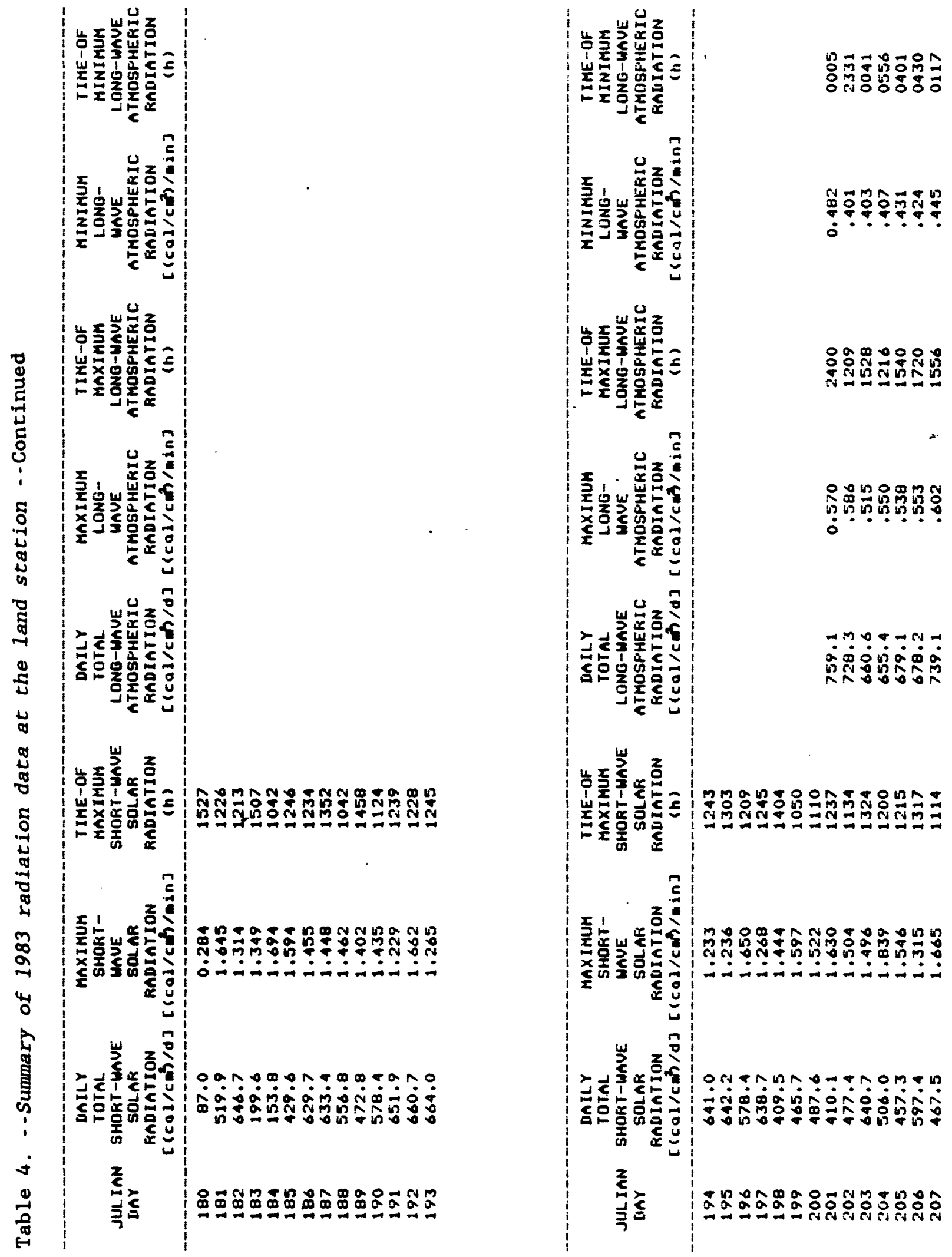

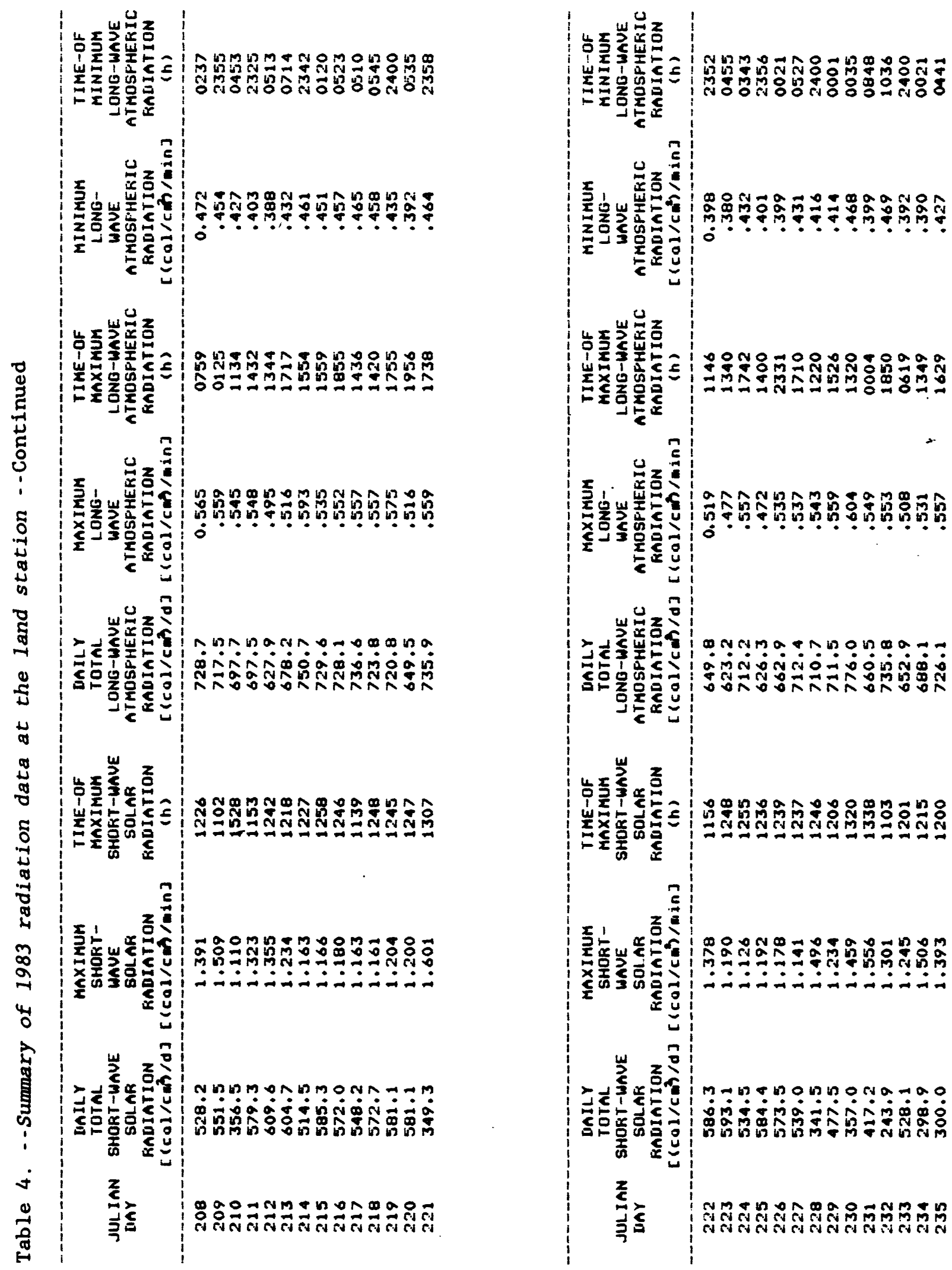

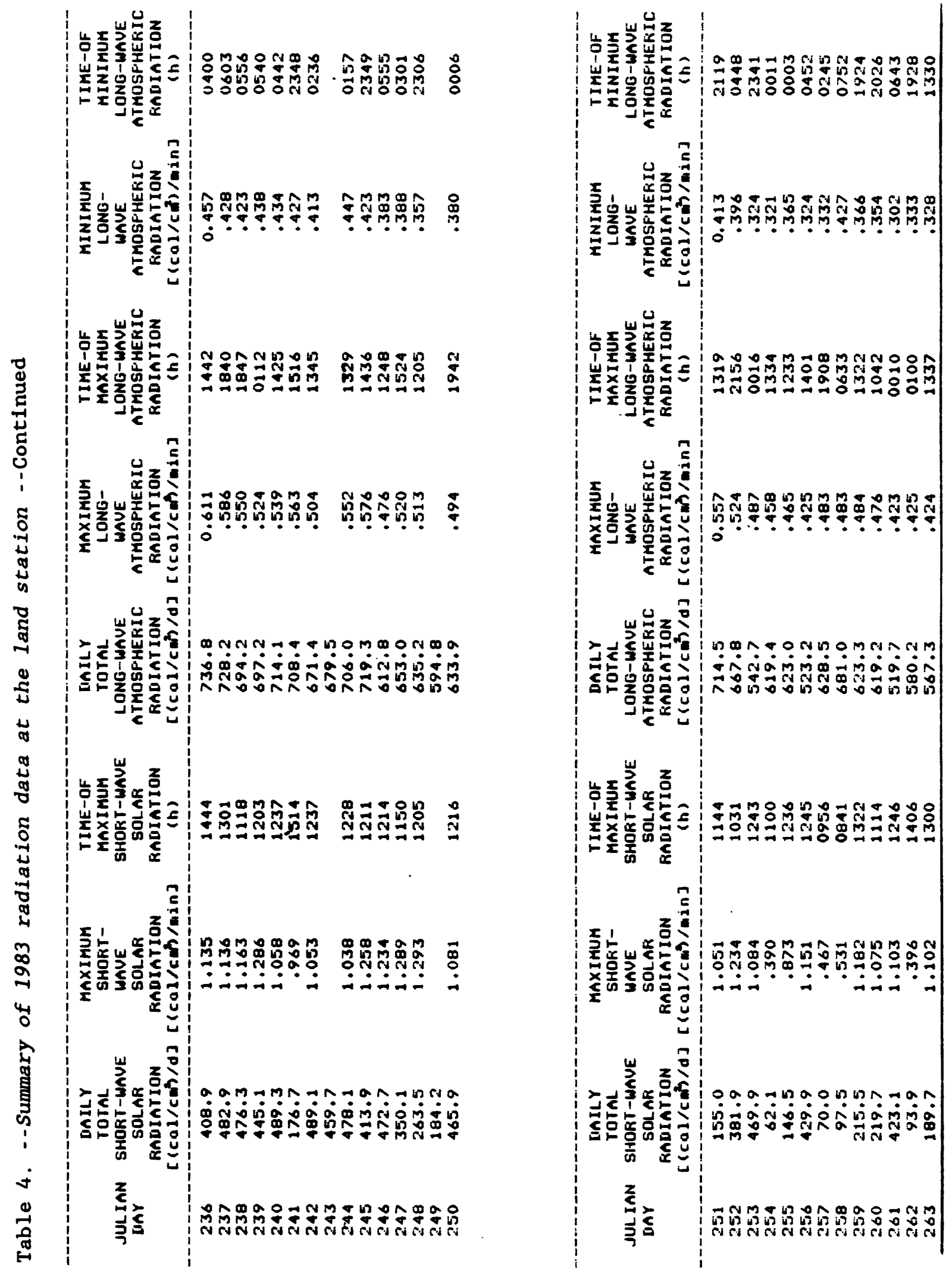


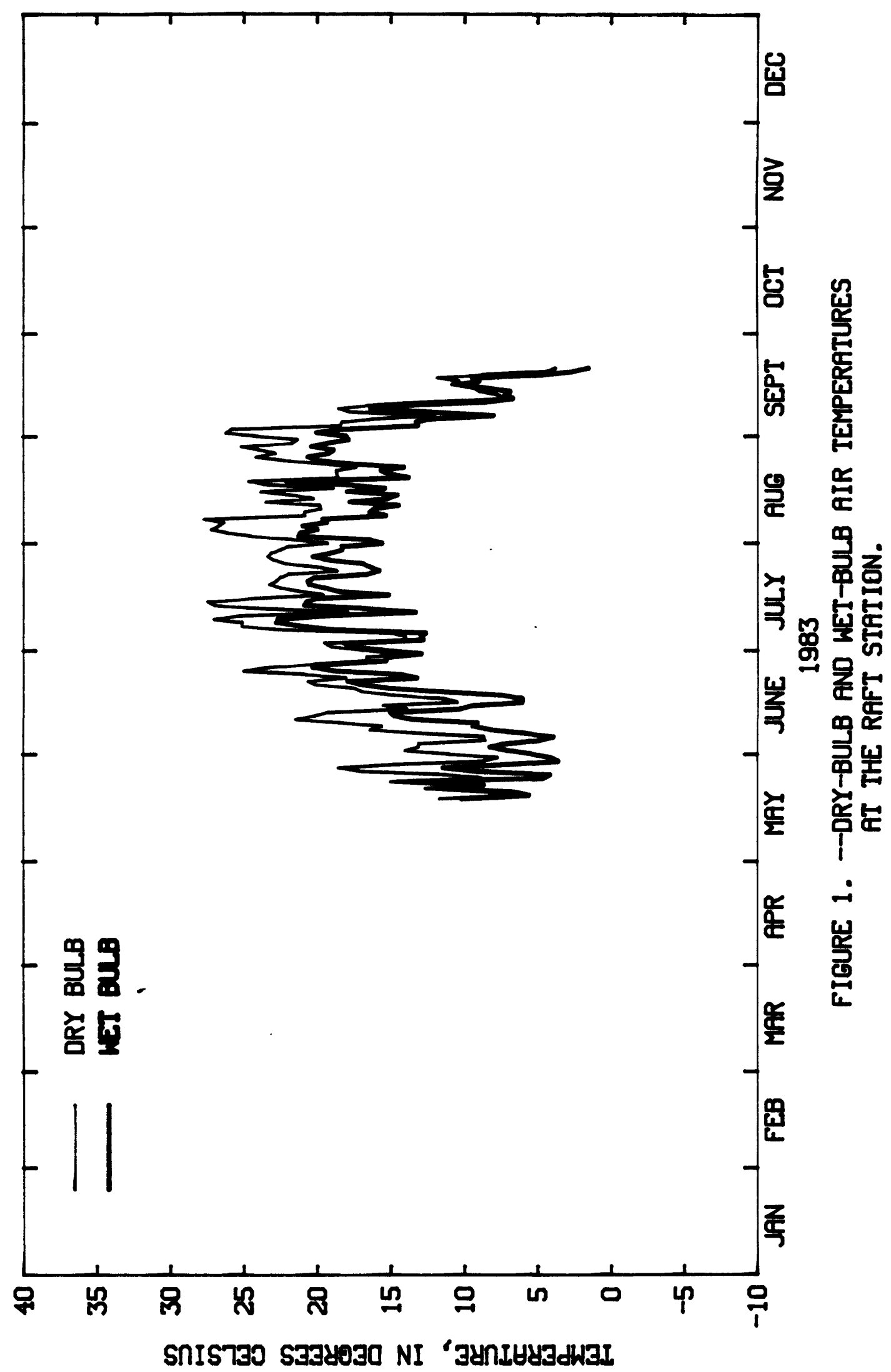




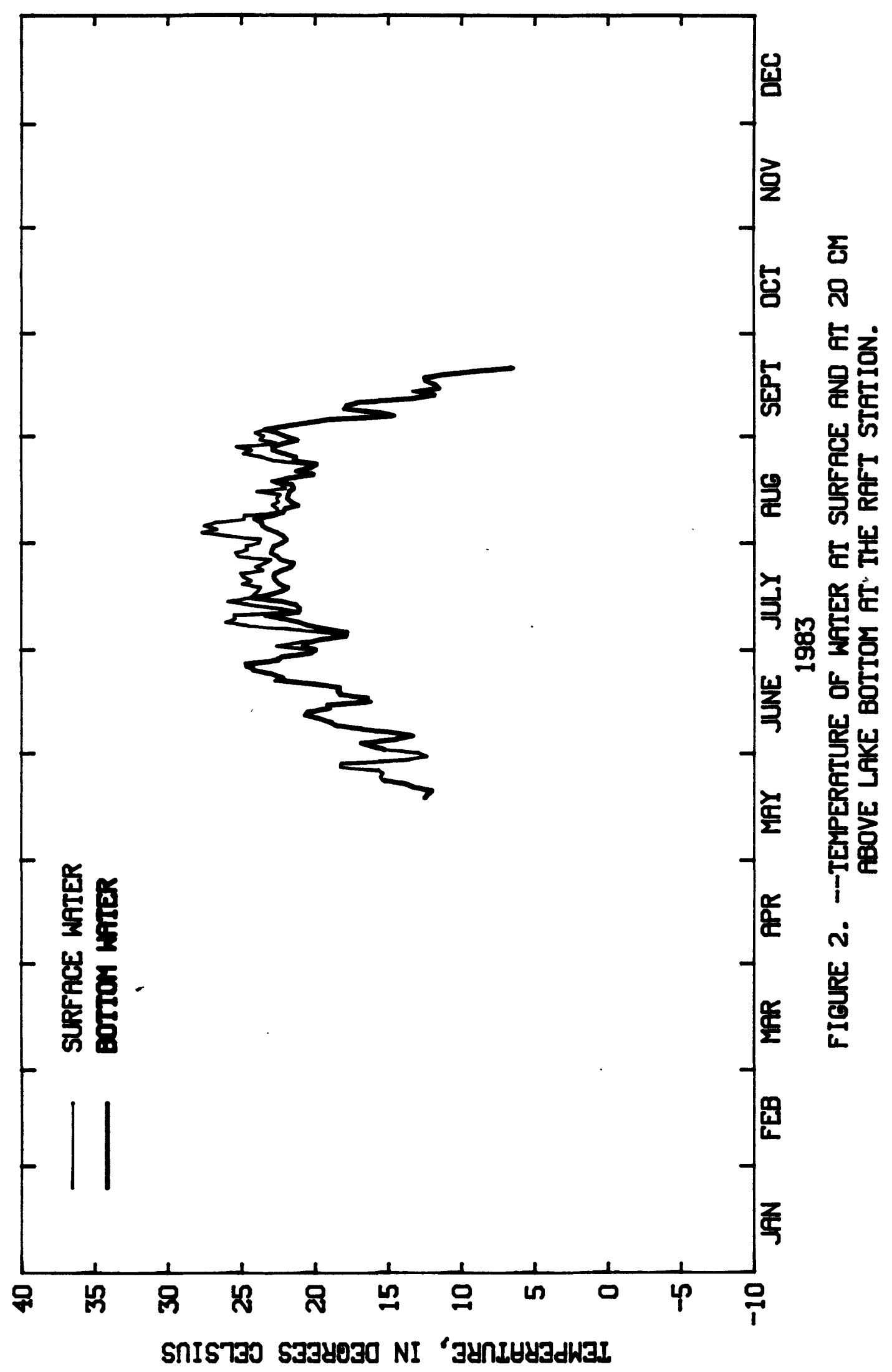




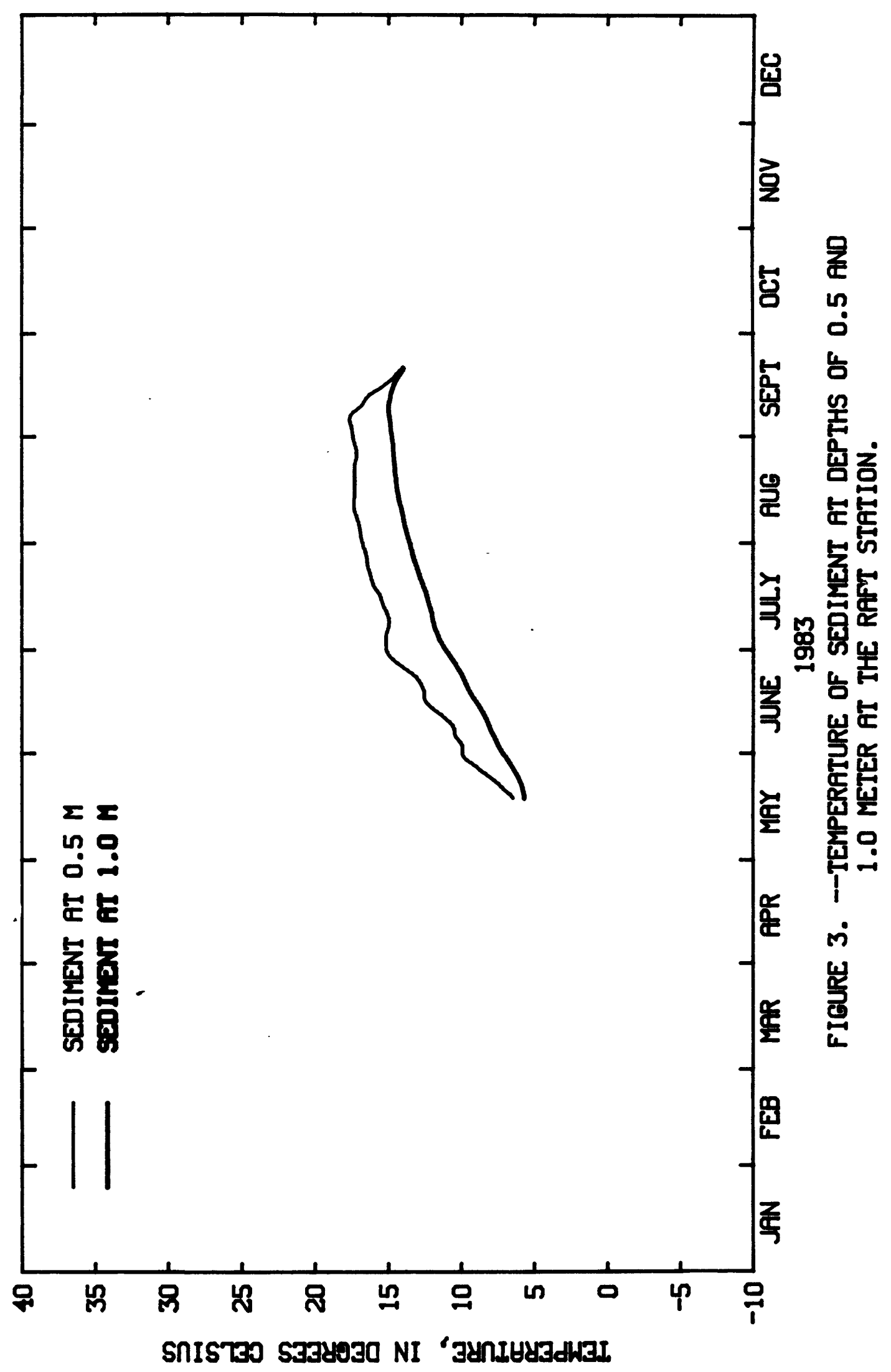

